\title{
The information and Communication Technologies in Tourism Degree Courses: the Reality of Portugal and Spain
}

\author{
Elisabete Paulo Morais, Carlos Rompante Cunha and João Pedro Gomes \\ Polytechnic Institute of Bragança - ESACT, Mirandela, Portugal
}

Correspondence should be addressed to: Elisabete Paulo Morais; beta@ipb.pt

Received date: 13 May 2013; Accepted Date: 26 May 2013; Published Date: 13 August 2013

Copyright (c) 2013. Elisabete Paulo Morais, Carlos Rompante Cunha and João Pedro Gome.

Distributed under Creative Commons CC-BY 3

\begin{abstract}
The developments occurring in recent years in the Information and Communication Technologies led inevitably to a great effect on the operation, structure and strategy of organizations around the world, and obviously also in the tourist sector organizations. With the rapid expansion of Information and Communication Technologies (ICT) throughout almost all aspects of tourism and hospitality industries, the task of integrating technology into education curriculum will be a need. Information and Communication Technologies appear one of the most critical area to the success of tourism in the future and the way it will promote the tourist destinations. This paper aims to analyze the relevance given by the various Portuguese and Spanish institutions of higher education to Information and Communication Technologies in their degrees. The analysis carried out was done in degree courses operating in this school year, 2012/2013, in Portuguese and Spanish universities and polytechnics, public and private.
\end{abstract}

Keywords: Tourism, Information and Communication Technologies (ICT), Higher Education

\section{Introduction}

Tourism is reputed to be the world's largest industry. Its revenues support a significant proportion of the economies of many nations and it is one of the largest employers worldwide. Its contribution to gross national product, employment and regional development are well documented and, unlike many other sectors, it is forecast to grow in importance in the coming decades as leisure time increases (Tahayori and Moharrer, 2006).

Cite this Article as: Elisabete Paulo Morais, Carlos Rompante Cunha and João Pedro Gomes (2013), " The information and Communication technologies in Tourism degree courses: the reality of Portugal and Spain" Journal of e-Learning an Higher Education, Vol. 2013 (2013), Article ID 611948, DOI: 10.5171/2013. 611948. 
Technology-enabled tourism, commonly referred to as e-tourism, is now impacting every aspect of how hospitality and tourism organizations conduct business. Industry members are forced to keep up with new technologies to remain competitive, and hospitality and tourism graduates are increasingly challenged to bring forward current skills and competencies in the field of e-tourism. The need to constantly update educational curriculum is critical, as new technologies continue to span across hospitality organizations and the globe (Elliot \& Joppe, 2009).

Tourism is acknowledged to be very information intensive. Tourists need information before going on a trip to help them plan and choose between options, and also increasingly need information during the trip as the trend towards more independent travel increases.

The new and rapid growth of ICT has changed the face of the word. ICT has become the main influential determinant in economic, social and human development (Dertouzos, 1997; Khasawneh and Ibrahim, 2012).

Technological progress and tourism have been going hand in hand for years (Buhalis, 2008). Since the 1980s, ICT has been transforming tourism globally. Developments in ICTs have undoubtedly changed both business practices and strategies as well as industry structures (Porter, 2001). The establishment of the Computer Reservation Systems (CRSs) in the 1970s and Global Distribution Systems (GDSs) in the late 1980s, followed by the development of the Internet in the late 1990s, have transformed the best operational and strategic practices in the industry dramatically (Buhalis, 2003; eBusiness W@tch, 2006). If the past 20 years have seen an emphasis on technology per se, then since the year 2000 we have been witnessing the truly transformational effect of the communications technologies. This has given scope for the development of a wide range of new tools and services that facilitate global interaction between players around the world.
The role of ICT in tourism industry cannot be underestimated and it is crucial driving force in the current information driven society. It has provided new tools and enabled new distribution channels, thus, creating a new business environment. ICT tools have facilitated business transaction in the industry by networking with trading partners, distribution of product services and providing information to consumers across the globe. On the other hand consumers are also using online to obtain information and plan their trip and travel. Information is the key element in the tourism industry. ICT pervades almost all aspects of tourism and related industry. For instance, we depend upon it right from the scratch while identifying and developing tourism site and destinations itself. The use of Geospatial Information Technologies in the recent years across the globe for varied purposes is popularly known and Tourism industry has not been an exception in availing its advantages. It can be used by tourist professionals to define the boundaries of the proposed tourist site as well its surrounding areas and the communities living in it. It can also get information on roads linking to the sites and availability of other utilities like water, power, market etc.

People, we are frequently told, are a critical dimension within the successful delivery of tourism services. "The story of successful tourism enterprises is one that is largely about people-how they are recruited, how they are managed, how they are trained and educated, how they are valued and rewarded, and how they are supported through a process of continuous learning and career development" (Fáilte, 2005).

This paper aims to analyze the relevance given by the various Portuguese and Spanish institutions of higher education to Information and Communication Technologies in their degrees. The analysis carried out was done in degree courses operating in this school year, 2012/2013, in Portuguese and Spanish universities and polytechnics, public and private.

\section{Tourism Education and ICT}

The adoption and diffusion of educational technologies that leverage ICT and the 
Internet has provided an unprecedented opportunity for improving higher education around the world (Davis and Wong, 2007). Therefore, educational technologies must become more popular among developing nations which seek economic improvement (Khasawneh et al., 2011). In fact, the educational technology is becoming more universal at an increasing rate as most firms recognize the needs to prepare the ICT professionals for the global environment (Margavio, 2005). The adoption and diffusion of educational technologies that leverage ICT and the Internet has provided an unprecedented opportunity for improving higher education around the world (Davis and Wong, 2007). Therefore, educational technologies must become more popular among developing nations which seek economic improvement (Khasawneh et al., 2011).

In all the discussion forums of tourism jobs, appears Informatics and use of Information Technology as one of the most desirable skills for the future professional. Ramos (2009) argues that competitiveness and exploitation of the tourism industry increasingly depends on the ability of professionals and managers take advantage of the emerging ICT to increase competitive benefits, since ICT allows adding value by facilitating the differentiation of the tourism product and increasing efficiency (Ramos, 2009).

Cheung and Law (2000) recommended that educators constantly update teaching content to provide an adequate supply of graduates with IT skills to meet the growing demands of the hospitality and tourism industry. Chan and Coleman (2004) pointed out that a qualified employee should have a combination of a good educational background and knowledge of IT, among other competencies, to offer higher standards to increasingly demanding guests. With the growing significance of e-commerce and its impact on hospitality and tourism, it is crucial for educational programs to offer courses in this area.

One of the fundamental challenges facing tourism professionals is the need for continuous adaptation to changes, due to the dynamism of the sector (Pilar, 2007). It is through the training of human resources in the tourism industry, especially in ICT, which improves their ability to adapt and consequently is increased flexibility and interactivity productive processes which result to be increasingly complex, due to the competitiveness and globalization currently existing (Buhalis, 2008). The improvement in the training of professionals, will greatly increase both the quality of services provided to customers, and the level of quality of information provided to customers.

Joaquim Majó (1999) does highly relevant considerations regarding higher education in Tourism and particularly on ICT (Majó, 1999):

- ICT should not only be seen as a specific matter and individual of tourism;

- ICT in higher education should be seen as supporting the dissemination of knowledge of the different matters. In this sense, ICT should be seen as essential to achieving the goals of higher education in tourism;

- The working hours available for some course units may call into question the quality of their teaching, as may be the case of ICT course units;

- The teaching staff should be aware that recycling and training must also be to update your computer skills and thus improve the performance of their classes;

- The problem that is associated with the number of computers per student and free time for self-learning in the classroom is closely connected with problems of costs;

- Students should be aware that the learning of ICT tools does not end in the classroom. Must make a continued learning outside of school hours;

- Institutions of higher education should not only teach the basic content for use "domestic". It is necessary to give other advanced content and specific of tourism for a good preparation of future professionals;

- Finally, the time spent on technology education should not be devoted to teaching programming, but learning to use tools, because the goal is to form good and 
knowledgeable users of the medium in order to enjoy all the features offered by ICT.

Even before the Bologna process had authors who argued that degrees in tourism beyond the pure ICT content should contain other, such as:

- Information Systems;

- Database Systems;

- Use of CRS (Central Reservation System) and GDS (Global Distribution System);

- Systems to promote tourism (multimedia environments);

- Telematics networks: Internet (both as a source of information as a mean of promotion and marketing through web pages);

- Local networks, use of intranets and extranets;

- Analysis of the main management programs tourist companies (both at the front-office and back-office);

- Geographic Information Systems.

Argue that this type of training should cover between $15-30 \%$ of the dedication of the student (Buhalis, 1998; Majó, 2004).

People are often critical dimension within the successful tourism service businesses. The history of successful businesses in the tourism sector resides above all about people, how they are recruited, how they are managed, trained, educated, the way they are valued and rewarded and how they will be supported through a process (Fáilte, 2005, Baum, 2007).

\section{Methodology}

The nature of objectives led to a methodology of quantitative research, descriptive and interpretative eminently possible that characterizes the object of study. The study focused on the analysis of
ICT training courses in tourism, because we believe ICT, especially in the context of the Bologna process, as basilar course units in curriculum structure, and are fundamental to the development and innovation tourism.

The research of the courses for this study was based on the website of the Directorate General of Higher Education (www.dges.mctes.pt) in the case of Portugal and the State Department of Education for Spain (www.educacion.gob.es). We considered only the courses in the area of tourism. After collection of the courses available in the school year 2012/2013, to obtain the remaining data was done by consulting the information available on the websites of the various institutions.

\section{Analysis of Data Obtained}

From the analysis carried out it was found that exist in Portuguese higher education 39 degrees in tourism, with 10 different designations, distributed by 30 higher education institutions (15 of 15 Private Higher Education and Public Higher Education). Of 39 degrees, 3 degrees are post-labour, and the remaining 36 the normal arrangements.

When analysed data from the Spanish higher education verified that there are 67 degrees in the area of tourism, with only 5 different designations, distributed by 52 higher education institutions. The term "Tourism" is predominantly utilized (there are 60 degrees with the designation "Tourism"). When analysed the education subsystem in Spain it was found that 53 degrees are the subsystem Public and 14 degrees are the private subsystem.

The geographical distribution of courses by NUTS II, to Portugal, and communities to Spain, are represented in Figure 1 and Figure 2, respectively. 


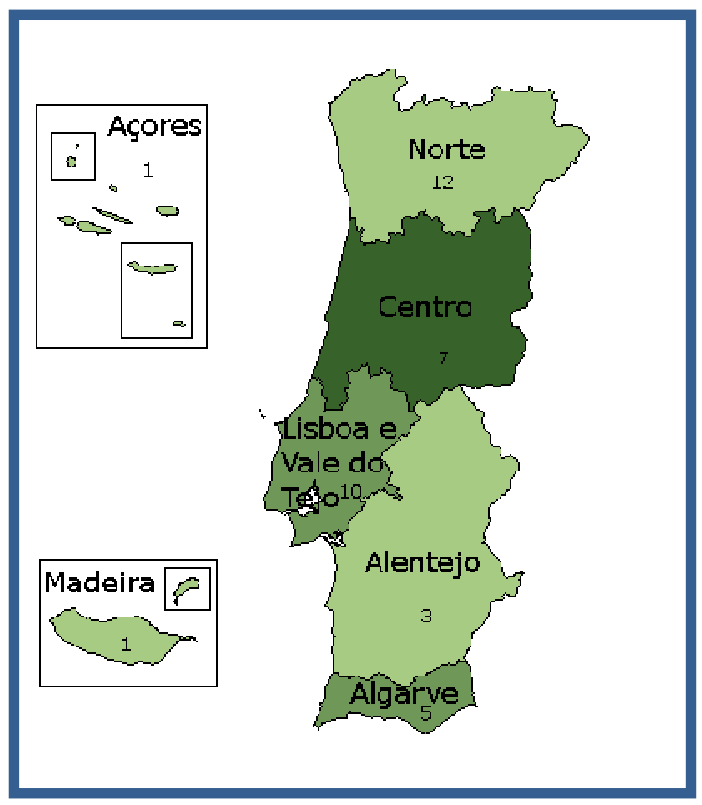

Figure 1: Courses Distribution in Portugal

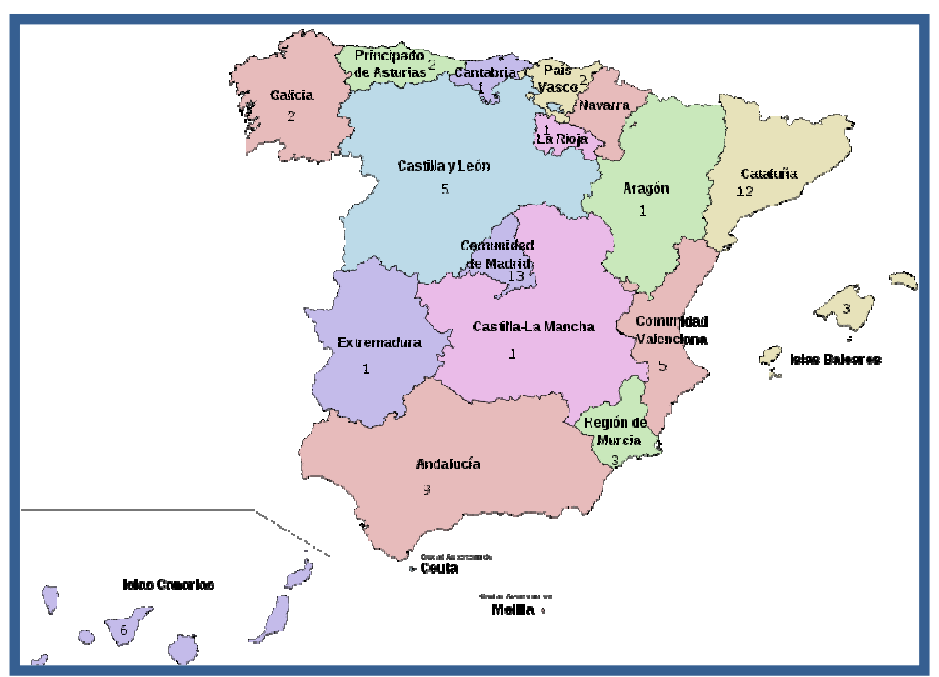

Figure 2: Courses Distribution in Spain

Table 1 shows the different designations and number of respective degrees, for the school year 2012/2013, both for Spain and for Portugal. 
It is interesting to note that Portugal, despite having fewer degrees, has more different designations. However, in both countries the predominant designation is "tourism", as it would be expected. In both countries there is a higher concentration of degrees in areas where the population is more abundant.

Table 1: Number of degrees in Tourism scientific area

\begin{tabular}{|c|c|c|}
\hline Degree & $\begin{array}{l}\text { Number of Degrees in } \\
\text { Spain }\end{array}$ & $\begin{array}{l}\text { Number of Degrees in } \\
\text { Portugal }\end{array}$ \\
\hline Tourism Entertainment & 0 & 1 \\
\hline Ecotourism & 0 & 1 \\
\hline $\begin{array}{l}\text { Leisure Management and Tourism } \\
\text { Animation }\end{array}$ & 1 & 1 \\
\hline Information and Tourism Animation & 0 & 1 \\
\hline Touristic information & 0 & 1 \\
\hline Tourism management & 1 & 1 \\
\hline Tourism & 60 & 28 \\
\hline $\begin{array}{l}\text { Tourism and Tourism Enterprises } \\
\text { Management }\end{array}$ & 0 & 1 \\
\hline Tourism and Leisure & 0 & 1 \\
\hline Sustainable Tourism & 0 & 1 \\
\hline $\begin{array}{lll}\text { Entertainment } & \text { Tourism } & \text { and } \\
\text { Heritage } & & \end{array}$ & 0 & 1 \\
\hline $\begin{array}{l}\text { International Business Management } \\
\text { Tourism and Leisure }\end{array}$ & 2 & 0 \\
\hline Tourism and Hotel Management & 1 & 0 \\
\hline Hotel and Tourism Management & 2 & 0 \\
\hline
\end{tabular}

Figure 3 shows the number of ECTS in the ICT area, and the number of degrees with the corresponding ECTS. From the data analysis should be noted that in Portugal there are 6 degrees that do not have any curricular unit in the scientific area of ICT. When we analyzed the data in Spain, the situation seems to be even more problematic, since 22 degrees did not have any curricular unit in the scientific area of ICT (corresponds to about 33\% of the degrees). When we recognize the importance of ICT for development and expansion of tourism, it is critical to have higher levels of education that do not give importance to a critical area such as ICT. 
Both in Portugal and in Spain, 6 ECTS is the number that gathers more degree courses. This is equivalent, in most cases, to have a single curricular unit of ICT, which is manifestly a reduced number. The maximum ECTS of ICT in Spain are 18 and in Portugal the maximum number of ECTS is 14.

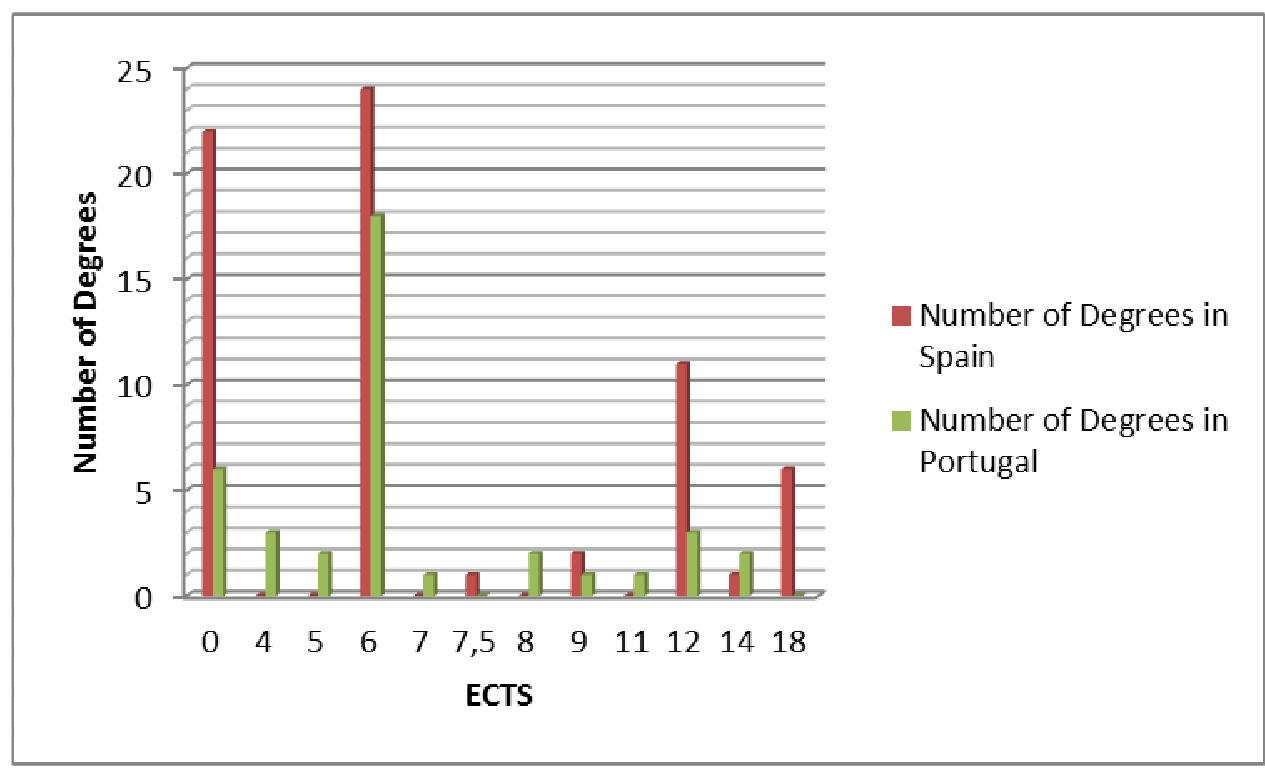

Figure 3: Number of ECTS by Degrees

Of the curricular units in the scientific area of ICT were identified 29 different designations for the case of Portugal and
36 to Spain. These curricular units are listed in Table 2.

Table 2: Curricular Units in scientific area of ICT

\begin{tabular}{|c|c|}
\hline $\begin{array}{l}\text { Curricular Units in Scientific area of ICT in } \\
\text { Portugal }\end{array}$ & $\begin{array}{l}\text { Curricular Units in Scientific area of ICT in } \\
\text { Spain }\end{array}$ \\
\hline Computer Applications in Tourism & $\begin{array}{l}\text { Learning and Information Technology and } \\
\text { Communication }\end{array}$ \\
\hline Computers & Computer Management \\
\hline Computers for Tourism & Computer Systems Applied to Tourism \\
\hline Computing applied to tourism & Computer tourism management \\
\hline Digital Technologies Applied to Tourism & $\begin{array}{l}\text { Computing applied to the Tourism Enterprises } \\
\text { Management }\end{array}$ \\
\hline E-Communication and Multimedia & Computing applied to tourism I \\
\hline General Principles of Informatics I & Computing applied to tourism II \\
\hline General Principles of Informatics II & Computing applied to tourism management \\
\hline Geographic Information Systems & E Distribution \\
\hline ICT Applied to Tourism & Electronic Business \\
\hline
\end{tabular}




\begin{tabular}{|c|c|}
\hline Information and Communication Technologies & $\begin{array}{l}\text { Geographic Information Technology Oriented } \\
\text { to Analysis and Diagnosis of Tourist } \\
\text { Resources }\end{array}$ \\
\hline Information Systems & $\begin{array}{l}\text { Geographic Information Technology Oriented } \\
\text { to Tourism Destination Management }\end{array}$ \\
\hline $\begin{array}{l}\text { Information Systems and Communication for } \\
\text { Tourism }\end{array}$ & $\begin{array}{l}\text { Global Distribution Systems in Travel } \\
\text { Agencies }\end{array}$ \\
\hline Information Systems Animation & Hotel Management Software Tools \\
\hline Information Systems applied to Tourism & ICT and Tourism \\
\hline Information Systems for Management & ICT applied to tourism \\
\hline Information Systems in Tourism & Information and Knowledge Management \\
\hline Information Systems Management & Information Systems and ICT I \\
\hline Information Technology & Information Systems and ICT II \\
\hline IT Management & $\begin{array}{l}\text { Information Systems Applied to Tourism } \\
\text { Management }\end{array}$ \\
\hline Knowledge Management & $\begin{array}{l}\text { Information systems for managing tourist } \\
\text { company }\end{array}$ \\
\hline Mathematics and Informatics & Information Technology and Communication \\
\hline New Technologies in Tourism & Information Technology in Tourism \\
\hline Reservation Systems and Information Flows & Introduction to ICT Skills \\
\hline Technological Innovation in Tourism & IT applied to the hospitality \\
\hline Technologies and Information Systems & $\begin{array}{l}\text { Management Information Systems for } \\
\text { Business Tourism }\end{array}$ \\
\hline $\begin{array}{l}\text { Technologies and Information Systems in } \\
\text { Tourism }\end{array}$ & $\begin{array}{l}\text { Management of hotel and facilities } \\
\text { information systems }\end{array}$ \\
\hline Technology and Information Systems I & Multimedia Tools \\
\hline \multirow[t]{8}{*}{ Technology and Information Systems II } & New Technologies in the Field of Tourism \\
\hline & Search and Information Management \\
\hline & Search techniques and use of information \\
\hline & $\begin{array}{l}\text { Systems and technologies for information } \\
\text { management }\end{array}$ \\
\hline & Technology and Innovation in Tourist Firms \\
\hline & Tourism and Electronic Business \\
\hline & Tourism information systems \\
\hline & Training in the Use of ICT \\
\hline
\end{tabular}


Most institutions have study plans available on their Web-sites; however, when one intends to analyze the detailed program contents of the curriculum units that are part of the curriculum few institutions have this information available.

\section{Conclusions}

The demands of the working world define a new profile for tourism professionals, requiring, in addition to knowledge, skills necessary to act and position themselves in front of situations.

With the current economic context to be based on the knowledge society, ICTs, particularly with the proliferation of Internet use, play a key role in all sectors of the industry in general, and tourism in particular.

This paper shows values related to ICT, and the weight that the curricular units of ICT have in the plans for undergraduate studies in the tourism sector in the Iberian Peninsula, and concluded that on average, curricular units of ICT represent about 3\% of the ECTS in Tourism degrees, and not $15 \%-30 \%$ as some authors argue that it should be (Buhalis, 1998; Majó, 2004).

When we find that the evolution of the tourism industry has been principally on the ICT, in our opinion, the graduate should be redesigned in order to become professionals with more and better skills in ICT.

Most of the courses do not prepare their students in order to acquire skills in the area of Geographic Information Systems and Multimedia, among others.

In most cases the courses have a curricular unit in the ICT area, where practically address office tools. As we have detected many courses do not have any curricular unit of ICT area (6 in Portugal and 22 in Spain, which corresponds to $15 \%$ and $33 \%$ respectively of the courses).

\section{References}

Baum, T. (2007). Human resources in tourism: Still waiting for change," Tourism Management, vol. 28, pp. 1384-1399, 2007.
Buhalis, D. (1998). "Information Technologies in tourism: Implications for the tourism curriculum," in Information and Comunications Technologies in tourism, Istanbul, 1998.

Buhalis, D. (2003). eTourism: Information technology for strategic tourism management. Pearson (Financial Times/Prentice-Hall).

Buhalis, D. \& Law, R. (2008). Progress in information technology and tourism management: 20 years on and 10 years after the Internet-The state of eTourism research. Tourism Management, vol. 29, pp. 609-623.

Chan, B., \& Coleman, M. (2004). Skills and competencies needed for the Hong Kong hotel industry: The perspective of the hotel human resources manager. Journal of Human Resources in Hospitality \& Tourism, 3(1), pp. 3-18.

Cheung, L., \& Law, R. (2000). Industrial information technology applications: Have hospitality and tourism graduates learned the needed skills? Journal of Hospitality and Tourism Education, 12(2), pp. 19-23.

Davis, R. \& Wong, D. (2007). "Conceptualizing and Measuring the Optimal Experience of the eLearning Environment," Decision Sciences Journal of Innovative Education, 5(1), pp. 97-126.

Dertouzos, M. L. (1997). What Will Be: How the New World of Information Will Change Our Lives, San Francisco: Harper Collins.

eBusiness W@tch. (2006). ICT and ebusiness in the tourism industry, sector impact study, no. 08/2006, European Commission. /http://www.ebusinesswatch.org/resources/tourism/SR082006_Tourism.pdfS.

Elliot, S. and Joppe, M. (2009). "A Case Study and Analysis of e-Tourism Curriculum Development" Journal of Teaching in Travel and Tourism, 9(3/4), pp. $230-247$.

Fáilte, I. (2005). A human resource development strategy for Irish 
Tourism. Competing through People, 2005-2012. Dublin: Fáilte Ireland.

Khasawneh, A., Khasawneh, M., Bsoul, M., Idwan, S. \& Turan, A. H. (2011). 'Models for Using Internet Technology to Support Flexible E-Learning,' Int. J. Management in Education.

Khasawneh, M. \& Ibrahim, H. (2012). A model for Adoption of ICT in Jordanian Higher Education Institutions: An Empirical Study. Journal of e-Learning \& Higher Education. Vol. 2012.

Majó, J. (2004) Las Tecnologías de la Información y las Comunicaciones en el," in V Congreso "Turismo y Tecnologías de la Información y las Comunicaciones" TuriTec 2004, Malaga, 2004.

Margavio, T., Hignite, M., Moses, D. \& Margavio, G. W. (2005). "Multicultural Effectiveness Assessment of students in
IS Courses," Journal of Information Systems Education, 16(4), pp. 421.

Pilar, M. L. (2007). "Posibilidades profesionales de los Diplomados de Turismo," Cuadernos de Turismo, vol. 20, pp. 131-151.

Porter, M. (2001). Strategy and the Internet. Harvard Business Review, 79(3), pp. 63-78.

Ramos, C., Rodrigues, P. \& Perna, F. (2009). Sistemas e Tecnologias de Informação no Sector Turístico. Revista Turismo \& Desenvolvimento, vol. 12, pp. 21-32.

Tahayori, H., Moharrer, M. (2006). ETourism :

The Role of ICT In Tourism Industry, Innovations And Challenges. http://195.130.87.21:8080/dspace/bit stream/123456789/778/1/Etourism $\% 20 \% 20$ the $\% 20$ role $\% 20$ of $\% 2$ 0ICT.pdf. 